\title{
Fermented milk beverage: formulation and process
}

\section{Márcio Rodrigues de Andrade ${ }^{1^{*}}$ (D) Thayrine Rodrigues Martins ${ }^{1}$ Amauri Rosenthal ${ }^{2}$ Júlia Tiburski Hauck ${ }^{1}$ Rosires Deliza ${ }^{2}$}

${ }^{1}$ Departamento de Tecnologia de Alimentos, Universidade Federal Rural do Rio de Janeiro (UFRRJ), 23890-000, Seropédica, RJ, Brasil. E-mail: m.andrade0109@gmail.com. "Corresponding author.

${ }^{2}$ Embrapa Agroindústria de Alimentos, Rio de Janeiro, RJ, Brasil.

ABSTRACT: Dairy products are an adequate alternative as functional foods since they present excellent nutritional value, have wide acceptance with consumers, and are potential matrices for inoculation of probiotic microorganisms. The present study aimed to develop a fermented milk beverage with fruits and a probiotic culture included, to evaluate the acceptance of this product among consumers to define the ideal formulation, and to perform Lactobacillus acidophilus counting in order to characterize the product as a probiotic food. For the formulation of the beverage, milk, whey, sugar, and pasteurized orange and papaya pulps were used as main ingredients. The beverage formulation consisted of mixing the fruit pulps with a dairy substrate of milk and whey which was previously fermented using a mixed commercial probiotic ABT-5 culture. Six formulations were tested. The milk substrate was maintained at 70\%. These formulations consisted of $50 \%$ of mineral water and $50 \%$ of skimmed milk with a concentration of probiotics of $0.5 \mathrm{~g} / \mathrm{L}$. Sugar concentration varied between $40 \mathrm{~g}, 70 \mathrm{~g}$, or $100 \mathrm{~g}$. As for flavoring, the juice was composed of $180 \mathrm{~mL}$ of papaya and $120 \mathrm{~mL}$ of orange, or $150 \mathrm{~mL}$ of papaya and $150 \mathrm{~mL}$ of orange. Beverages were prepared and then stored at $5 \pm 1^{\circ} \mathrm{C}$. These products were evaluated after 24 hours of preparation/storage by 90 tasters (consumers) for acceptance and sensory characterization. Data were analyzed by ANOVA. The differences between samples were evaluated using the Tukey test at a significance level of 5\%. Acceptance of the beverage samples among tasters varied from 5.1 to 6.9 and ranged between the hedonistic terms I neither liked nor disliked it and somewhat enjoyed it in a 9-point hedonic scale. The enumeration of Lactobacillus acidophilus LA-5 ranged from 7.83 to $8.09 \mathrm{log} C F U / m L$ in the first week of refrigerated storage. Our results suggested that the beverages analyzed were suitable for inoculation of probiotics and met the legislation requirements. Therefore, these beverages should be classified as probiotic products. Samples with 10\% sugar were the least preferred by the study participants whereas beverages containing $40 \mathrm{~g}$, $70 \mathrm{~g}$ and $180 \mathrm{~mL}$ of papaya juice and $120 \mathrm{~mL}$ of orange juice and the sample with $70 \mathrm{~g}$ of sugar, $150 \mathrm{~mL}$ of papaya juice, and $150 \mathrm{~mL}$ of orange juice did not differ significantly from each other in terms of acceptance and were; therefore, the 3 formulations that received the highest means of acceptance by consumers. Key words: milk beverage, probiotics, sensory analysis.

\section{Bebida láctea fermentada: formulação e processo}

RESUMO: Produtos lácteos são uma alternativa adequada como alimentos funcionais por apresentarem excelente valor nutricional, por serem amplamente aceitos e consumidos além de apresentar potenciais matrizes para inoculação de microrganismos probióticos. O objetivo deste estudo foi desenvolver uma bebida láctea fermentada com frutas adicionada de cultura probiótica e avaliar a aceitação entre os consumidores para definição da formulação ideal, bem como, realizar a contagem de Lactobacillus acidophilus para caracterização do produto como alimento probiótico. Para a formulação da bebida utilizou-se leite, soro de leite, açúcar e polpas de mamão e laranja pasteurizadas como principais ingredientes. A formulação das bebidas consistiu em misturar as polpas de frutas com uma base láctea de leite e soro de leite, previamente fermentada por cultura mista probiótica comercial ABT-5. Foram testadas seis formulações mantendo a base láctea fixa em 70\%, composta por 50\% de água mineral e 50\% de leite desnatado com a concentração de probióticos 0,5g/L, variando a concentração de açúcar em 40,70 ou 100ge, quanto à saborização, o suco foi composto por $180 \mathrm{~mL}$ de mamão e $120 \mathrm{~mL}$ de laranja, ou $150 \mathrm{~mL}$ de mamão e $150 \mathrm{~mL}$ de laranja. As bebidas elaboradas foram armazenadas a $5 \pm 1^{\circ} \mathrm{C}$ e após 24 h avaliadas por 90 avaliadores quanto à aceitação e a caracterização sensorial. Os dados foram analisados por ANOVA e as diferenças entre as amostras foi avaliada através do teste de Tukey, ao nivel de significância de 5\%. A aceitação das amostras variou de 5,1 até 6,9 situando-se entre os termos hedônicos não gostei nem desgostei e gostei regularmente em escala hedônica de nove pontos. A enumeração de Lactobacillus acidophilus LA-5 variou de 7,83 a 8,09log UFC/mL na $1^{a}$ semana de armazenamento refrigerado. Os resultados sugerem que as bebidas se mostraram adequadas para inoculação de probióticos e atenderam a exigência da legislação, sendo, portanto, um produto probiótico. As amostras com 10\% de açúcar foram as menos preferidas pelos participantes do estudo, enquanto as bebidas com teor de $40 \mathrm{~g}$ e $70 \mathrm{~g}$ e $180 \mathrm{~mL}$ de suco de mamão e $120 \mathrm{~mL}$ de suco de laranja e a amostra com $70 \mathrm{~g}$ de açúcar e $150 \mathrm{~mL}$ de suco de mamão e $150 \mathrm{~mL}$ de suco de laranja não diferiram significativamente entre si quanto à aceitação, tendo sido, portanto, as três formulações que receberam as médias mais altas de aceitação pelos consumidores.

Palavras-chave: bebida láctea, probióticos, análise sensorial.

\section{INTRODUCTION}

Dairy products are good matrices for probiotic inoculation (FERNANDES PEREIRA \& RODRIGUES, 2018). Their components (ingredients) are sources of protein, minerals, and vitamins that provide favorable environment for the development of probiotics (HE \& HEKMAT, 2014; VAN HOOIJDONK \& HETTINGA, 2015). Yogurts, milk-based beverages, and fermented milks are among the top, major probiotic foods consumed worldwide. However, food should contain an adequate 
concentration of probiotics; i.e., above $10^{6} \mathrm{UFC} / \mathrm{g}$ when consumed in order to have a beneficial effect on health (LOURENS-HATTINGH \& VILJOEN, 2001; JAYAMANNE \& ADAMS, 2006; FERNANDES PEREIRA \& RODRIGUES, 2018; PEREIRA et al., 2018). Recent studies indicated that continuous consumption of probiotic foods promotes a number of benefits including balance of intestinal flora as well as increased resistance against pathogenic (ZHENG et al., 2014; ZOUMPOPOULOU et al., 2017). The Lactobacillus acidophilus strains are commonly used in milk products that produce organic acids (lactic acid, acetic acid, etc.) contributing to the balance of the intestinal flora (YERLIKAYA, 2014). In addition, strains of Bifidobacterium animalis subsp. lactis promote various health-related effects including resistance to pathogenic microorganisms (MOTA et al., 2015). Strains of Streptococcus thermophilus which are starter cultures in the production of yogurts have been reported as having probiotic potential. It has shown that these bacterial strains have beneficial effects to the health of humans such as prevention of gastritis and relief of lactose intolerance (KIANI, 2006; PRADO et al., 2008; MOKOENA et al., 2016; URIOT et al., 2017).

These potential multiple functional properties have resulted in an increased production of different types of fermented milk including those with fruits, nuts, herbs, and fibers in order to meet the increasing consumer demand (SHORI \& BABA, 2013; ZHANG et al., 2016; SU et al., 2017).

Fruit juices as well as dairy products offer several advantages for probiotic microorganisms (FERNANDES PEREIRA \& RODRIGUES, 2018). They are a rich source of nutrients (antioxidants, minerals, and vitamins) and their natural sugars contribute to the growth of probiotics. Citrus juices, especially orange juice, are sources of vitamin $\mathrm{C}$ and bioactive compounds with a wide range of biological activities and potential health benefits (LI \& SCHLUESENER, 2017). Vitamin C and beta-carotene which are present in juices may help prevent cancer since they confer a protective effect on cells against free radical damage, retarding cellular aging (CITRUSBR, 2017).

Brazil accounts for $34 \%$ of orange production and more than half of the global production of juice considering the last 5 harvests. According to worldwide survey carried out by the US Department of Agriculture (USDA), Brazil contributes to $76 \%$ of the world's commercialization of orange juice consolidating itself as the most important global supplier of this noble food product.
Nevertheless, only $3 \%$ of the average of the last 5 harvests were consumed in the domestic market whereas the remaining $97 \%$ were destined for export (FAVA NEVES \& TROMBIN, 2017).

Banana, papaya, mango and other fruits are large fruit crops of tropical and subtropical areas (ALI et al., 2004; SAÚCO et al., 2014) which juices have high nutritional value (MEGÍAS-PÉREZ et al., 2014). Brazil is the largest producer and exporter of papaya catering to demanding markets such as the United States and Europe (SEBRAE, 2016). Ripe fruit pulp is used in the food industry to produce preserves, jellies, jams, juices, and nectars which are combined or not with other tropical fruits as well as puree by aseptic process or frozen (SEBRAE, 2016). In addition, papaya is a good source of calcium and an excellent source of provitamin A and vitamin $\mathrm{C}$ (SEBRAE, 2016).

Descriptive analysis has been the main tool of sensory science to obtain detailed, reliable and reproducible data to describe the sensorial profiles of food products (ALEXI et al., 2018). Within the product profile, a fundamental step is the selection of a formulation that is aligned as much as possible with the consumer preferences (VAN KLEEF et al., 2006). The CATA or "check-all-thatapply" questionnaire has been increasingly used as a fast method to obtain food and non-food product profiles (VARELA \& ARES, 2014). The method was used for the first time in market research in order to understand the consumer's perception of one particular brand (GRYGORCZYK et al., 2017). Due to the simple application, small requirements of cognitive effort and the rapid response of the sensory characteristics of the products assessed by the evaluators (consumers/tasters), the CATA questions, when compared to the several existing methods of sensorial analysis, gained popularity among researchers (ALEXI et al., 2018). In addition, CATA is a non-holistic method, i.e. the individual evaluates the sensory characteristics of the product. Simultaneous evaluation of all samples is not necessary in this method which makes it suitable for large product groups and/or when the monadic presentation order of samples is required (ARES, 2015).

The present study aimed to develop a papaya and orange flavored fermented dairy beverage mixed with probiotic culture and to identify the most appropriate formulation from a sensorial and nutritional standpoint. 


\section{MATERIALS AND METHODS}

Preparation of papaya and orange flavored fermented dairy beverages added with a ABT-5 mixed culture probiotic

The preparation of the dairy beverages followed the flowchart adapted from MASSON (2010) presented in figure 1. Skimmed raw milk was replaced by skimmed UHT milk. The fermentation time that was shortened from 210 $\min$ to $150 \mathrm{~min}$.

For the processing of the fermented dairy beverage with the addition of probiotics, the milk substrate was first made using whey powder (ALIBRA) and skimmed UHT milk (REGINA) purchased from local supermarkets and kept at room temperature until beverage started being produced. Petrópolis mineral water was purchased from supermarkets located in Barra da Tijuca neighborhood, municipality of Rio de Janeiro, State of Rio de Janeiro (RJ), southeast Brazil, and transported to the facilities of EMBRAPA Food Agri-industry A located in Rio de Janeiro, RJ, southeast Brazil.

Mixed probiotic culture ABT-5

(Christian Hansen) was used in composite powder of Bifidobacterium animalis subsp. lactis BB-12, Lactobacillus acidophilus LA-5, and Streptococcus thermophilus. As for the flavoring, pasteurized papaya flavored (MAISFRUTA) and orange flavored (BELA ISCHIA) commercial pulps, both products purchased from the Central Supply Store of Rio de Janeiro State (CEASA), southeast Brazil, and transported to EMBRAPA where they were kept at freezing temperature $\left(-18 \pm 1^{\circ} \mathrm{C}\right)$ until processing time. Commercial refined sugar (Açúcar União) was used to sweeten the beverage.

In order to obtain the beverage, first the milk substrate was prepared which consisted of the reconstitution of $9 \mathrm{~g} / 100 \mathrm{~mL}$ of whey in mineral water, added of UHT milk followed by heating in oven at $43^{\circ} \mathrm{C}$ per 150 minutes for fermentation until reaching the $\mathrm{pH}=4.6 \pm 0.2$. After fermentation, the milk substrate was transferred to B.O.D until the temperature reached $10^{\circ} \mathrm{C}$. Then pulps and sugar were added to the milk substrate according to each formulation to be evaluated. For all samples, $0.5 \mathrm{~g}$ of probiotic mixed culture (ABT5) was added to $1 \mathrm{~L}$ of the prepared beverage; i.e., $0.5 \mathrm{~g}$ of the probiotic was added to $700 \mathrm{~mL}$ of milk substrate in order to proceed with the fermentation. Six formulations of papaya flavored fermented milk beverage as shown in table 1 were prepared with the following coding: A (180 mL of papaya pulp, $120 \mathrm{~mL}$ of orange pulp, and $40 \mathrm{~g}$ of sugar), B (150 $\mathrm{mL}$ of papaya pulp, $150 \mathrm{~mL}$ of orange pulp, and $40 \mathrm{~g}$ of sugar), $\mathrm{C}$ (180 $\mathrm{mL}$ of papaya pulp, $120 \mathrm{~mL}$ of orange pulp, and $70 \mathrm{~g}$ of sugar), D (150 mL of papaya pulp, $150 \mathrm{~mL}$ of orange pulp, and $70 \mathrm{~g}$ of sugar), E (180 $\mathrm{mL}$ of papaya pulp, $120 \mathrm{~mL}$ of orange pulp, and $100 \mathrm{~g}$ of sugar), and $\mathrm{F}(150 \mathrm{~mL}$ of papaya pulp, $150 \mathrm{~mL}$ of orange pulp, and $100 \mathrm{~g}$ of sugar). Subsequently, the beverage was bottled in sterile bottles and stored under refrigeration at $5 \pm 1{ }^{\circ} \mathrm{C}$ for $24 \mathrm{~h}$.

\section{Microbiological analyses}

$25 \mathrm{~mL}$ aliquots of each milk beverage sample were aseptically put into sterile plastic bags,

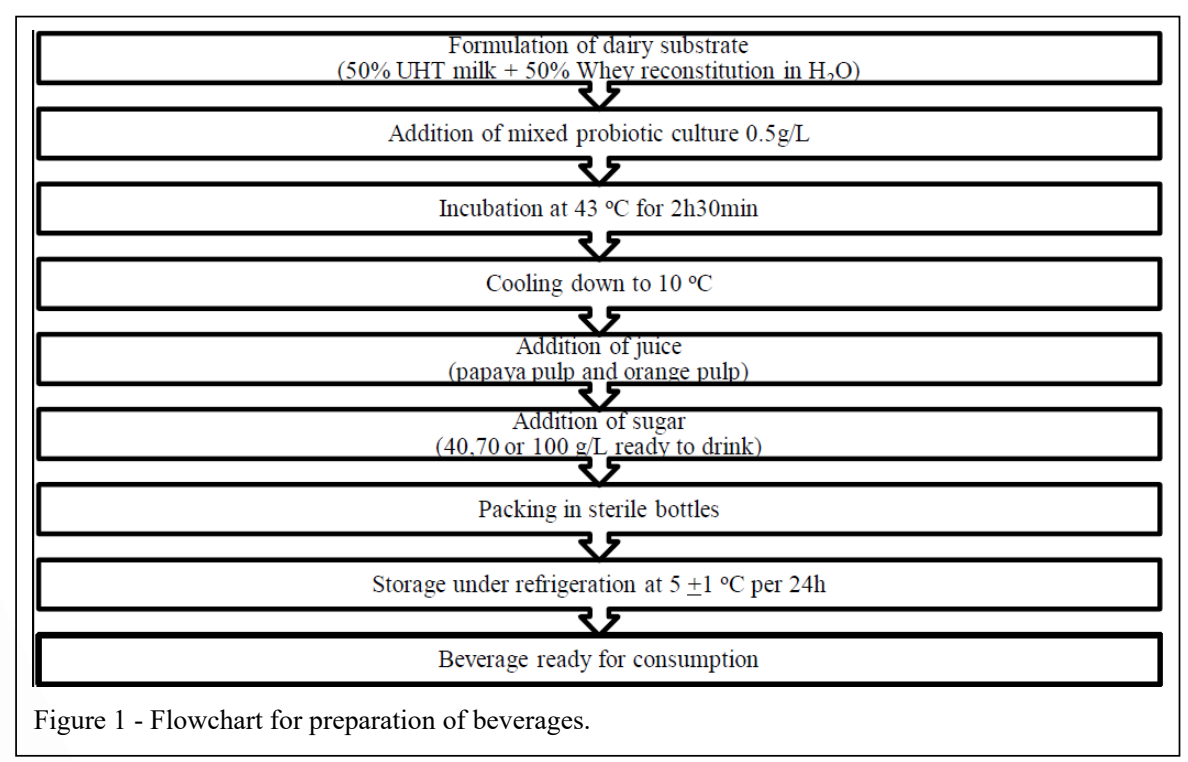

Ciência Rural, v.49, n.3, 2019. 
Table 1 - Formulations of the fermented dairy beverage flavored papaya and orange.

\begin{tabular}{lccc}
\hline Samples & $\begin{array}{c}\text { Papaya pulp } \\
(\mathrm{mL} / \mathrm{L})\end{array}$ & $\begin{array}{c}\text { Orange pulp } \\
(\mathrm{mL} / \mathrm{L})\end{array}$ & $\begin{array}{c}\text { Added sugar } \\
(\mathrm{g})\end{array}$ \\
\hline $\mathrm{A}$ & 180 & 120 & 40 \\
$\mathrm{~B}$ & 150 & 150 & 40 \\
$\mathrm{C}$ & 180 & 120 & 70 \\
$\mathrm{D}$ & 150 & 150 & 70 \\
$\mathrm{E}$ & 180 & 120 & 100 \\
$\mathrm{~F}$ & 150 & 150 & 100 \\
\hline
\end{tabular}

A - Fermented dairy beverage with 4\% sugar, $60 \%$ papaya pulp, and $40 \%$ orange pulp; B - Fermented dairy beverage with $4 \%$ sugar, $50 \%$ papaya pulp, and $50 \%$ orange pulp; C Fermented dairy beverage with $7 \%$ sugar, $60 \%$ papaya pulp, and $40 \%$ orange pulp; D - Fermented dairy beverage with $7 \%$ sugar, $50 \%$ papaya pulp, and $50 \%$ orange pulp; E - Fermented dairy beverage with $10 \%$ sugar, $60 \%$ papaya pulp, and $40 \%$ orange pulp; F - Fermented dairy beverage with $10 \%$ sugar, $50 \%$ papaya pulp, and $50 \%$ orange pulp.

weighed, and homogenized with $225 \mathrm{~mL}$ of $0.1 \%$ peptone water. Decimal dilutions from dilution $10^{-1}$ were prepared in tubes containing $9.0 \mathrm{~mL}$ of $0.1 \%$ peptone water. In addition to the enumeration of probiotics, the following analyses were performed: counting of thermally tolerant coliforms at $45^{\circ} \mathrm{C}$ according to AOAC (2000) using Petrifilm TM CC plates (3M Company, St. Paul, MN, USA) and determination of molds and yeasts, coagulase positive Staphylococcus counts and Salmonella spp. performed in a microbiology laboratory on day 1 and day 7 of storage using a methodology adapted from TOURNAS et al. (2001) and HITCHINS et al. (1998), according to the normative instruction no. 62 (BRASIL, 2003).

\section{Enumeration of Lactobacillus spp.}

Analysis of L. acidophilus in milk beverages was performed by complete homogenization of $25 \mathrm{~mL}$ of sample with $225 \mathrm{~mL}$ of peptone water. At least three 1:10 serial dilutions of the dairy beverage in peptone water were inoculated deeply in two De Man Rogosa Sharpe agar plates (MRS). Enumeration was conducted after incubation in aerobiosis at $37^{\circ} \mathrm{C}$ for $72 \mathrm{~h}$ (ASHRAF \& SHAH, 2011). Countings were performed on day 1 and day 7 of refrigerated storage $\left(5 \pm 1^{\circ} \mathrm{C}\right)$. Results were expressed in $\mathrm{CFU} / \mathrm{mL}$ and analyzed statistically through analysis of variance (ANOVA) using XLStat software (version 2016) in order to assess if there was a significant difference between the microbial counts in the samples of the different beverages at each evaluated storage time and for each beverage at different times. In case of a significant difference, the Tukey test was used in order to investigate the presence of significant differences between means at a significance level of $5 \%$.

Microbiological processing and analysis were performed in duplicate. For each dilution, plating was performed in duplicate with two replicates of the process in order to increase results reliability of.

\section{Acceptance evaluation and sensory characterization}

Ninety consumers of dairy products with ages between 18 and 65 years old were invited to participate in the study; $58 \%$ of these consumers were men. For such purpose, individuals had to enjoy drinking dairy beverages and be consumers of dairy products at least occasionally. The test was carried out in the individual booths at the Laboratory of Sensory and Instrumental Analysis of Embrapa Food Agri-industry (Rio de Janeiro, RJ, Brazil) under white light. The Fizz software (Biosystems, version 2015) was used for data collection. A sample was served monadically to each vollunteering participant in a $50 \mathrm{~mL}$ plastic cup coded with a three-digit number at $8 \pm 2{ }^{\circ} \mathrm{C}$ according to CATA terms and presentation sequence. Participants evaluated the overall acceptance of the samples using a structured 9-point hedonic scale questionnaire for sensory evaluation which ranged from "dislike extremely" (1) to " like extremely" (9). Then vollunteers were asked to list all CATA terms they considered appropriate to describe samples. CATA terms were identified in a preliminary study by 10 trained evaluators and consumers of dairy products (yogurt and dairy beverages) and included: acidity-acid, low acidity; sweetness-very sweet, sweet, sweet/acid balance; consistencygood consistency, poor consistency/watery; color -attractive color; flavor: fermented flavor, orange flavor, and papaya flavor; scent: fermented scent, sweet scent, mild scent; appearance: homogeneous appearance; sandy appearance.

After participants evaluated the 6 samples of papaya flavored and orange flavored probiotic fermented milk beverage, these individuals were asked to identify the terms that they considered more appropriate to describe the ideal dairy beverage and to fill out a sociodemographic questionnaire.

\section{Statistical analysis of data}

A XLStat software (version 2016) was used for the statistical analyses. Acceptance data 
were analyzed with Analysis of Variance (ANOVA) considering sample and consumer as cause of variation at the significance level of 5\%. The Tukey test was applied to assess if there was a significant difference between the averages considering $\mathrm{P} \leq 0.05$. The Internal Preference Map was used to illustrate individual consumer acceptance of fermented milk drink samples. The Cochran's Q test at the level of $(\mathrm{P} \leq 0.05)$ was used to determine which attributes of CATA issues most influenced samples sensory characterization.

\section{RESULTS AND DISCUSSION}

\section{Probiotic enumeration}

To be considered a probiotic, the product should present a concentration of probiotic microorganisms above $10^{6} \mathrm{CFU} / \mathrm{g}$ (JAYAMANNE \& ADAMS, 2006). Thus, the Technical Regulation on the Identity and Quality of Milk Beverages characterizes that added fermented dairy beverages should have a minimum count of $10^{6} \mathrm{CFU} \mathrm{g}^{-1}$ of viable lactic bacteria. The probiotic enumerations of the samples after preparation of the beverages and after 7 days of refrigerated storage are shown in table 2.

According to statistical analysis, there was a significant difference $(\mathrm{P} \leq 0.05)$ between the formulations and throughout refrigeration. According legal requirements (BRASIL, 2005), all samples had a concentration of $10^{7}$ to $10^{8}\left(\mathrm{CFU} \mathrm{g}^{-1}\right)$ of viable probiotic bacteria and can; therefore, be considered probiotic.

At the initial count, sample E, with 8.12 $\log \mathrm{CFU} / \mathrm{mL}$, sample F, with 8.09 and sample C, with $8.05 \log \mathrm{CFU} / \mathrm{mL}$ of viable microorganisms, were the ones that presented the highest number of probiotics. There was no difference between these samples. Similar behavior was also observed on the $7^{\text {th }}$ day of storage under refrigeration in which the same samples E, F, and C presented 7.88, 7.85, and $7.87 \log \mathrm{CFU} / \mathrm{mL}$ respectively, maintaining the highest concentration of viable microorganisms. Samples A, B, and D presented significantly lower counts in both analyzed times. Sample B had the lowest levels which were significantly different from the other samples. COSTA et al. (2014) reported high counts for $S$. thermophilus (8.99 log CFU/mL), L.delbrueckii ssp. bulgaricus (7.83 log $\mathrm{CFU} / \mathrm{mL}$ ), and L. acidophilus (8.99 $\log \mathrm{CFU} / \mathrm{mL}$ ) in goat milk-based yogurts after fermentation. Similar results were reported for $S$. thermophilus (9-11 log $\mathrm{CFU} / \mathrm{mL}$ ) and L. bulgaricus (8-9 $\log \mathrm{CFU} / \mathrm{mL})$ in yoghurts prepared from sheep milk (COSTA et al., 2014; BALTHAZAR et al., 2016). MACHADO et al. (2017) carried out a study on yogurt produced with goat milk with honey. These authors obtained approximately $8.5 \log \mathrm{CFU} / \mathrm{mL}$ for L. acidophilus on the first day of refrigeration of the product. All the studies cited attributed the development of $L$. acidophilus to a minimum amount of sugar in the formulations. Similarly, results presented in table 2 suggested that formulations with higher sugar levels (7\% and 10\%) achieved a higher L. acidophilus count during refrigeration.

Deteriorating and pathogenic microbiological profile Technical regulation on microbiological standards for food establishes that the acceptable

Table 2 - CFU/mL enumeration of Lactobacillus spp. during storage ${ }^{\S}$.

\begin{tabular}{|c|c|c|c|c|c|c|}
\hline Time (days) & A & B & $\mathrm{C}$ & $\mathrm{D}$ & $\mathrm{E}$ & $\mathrm{F}$ \\
\hline 1 & $7.94 \pm(0.01)^{\mathrm{Ba}}$ & $7.83 \pm(0.01)^{\mathrm{Ca}}$ & $8.05 \pm(0.01)^{\mathrm{Aa}}$ & $7.98 \pm(0.01)^{\mathrm{Ba}}$ & $8.12 \pm(0.01)^{\mathrm{Aa}}$ & $8.09 \pm(0.01)^{\mathrm{Aa}}$ \\
\hline 7 & $7.71 \pm(0.04)^{\mathrm{Bb}}$ & $7.60 \pm(0.01)^{\mathrm{Cb}}$ & $7.87 \pm(0.01)^{\mathrm{Ab}}$ & $7.73 \pm(0.01)^{\mathrm{Bb}}$ & $7.88 \pm(0.01)^{\mathrm{Ab}}$ & $7.85 \pm(0.02)^{\mathrm{Ab}}$ \\
\hline
\end{tabular}

${ }^{\S}$ Refrigerated $\left(5 \pm 1^{\circ} \mathrm{C}\right)$ for 7 days.

Means with equal uppercase letters on the same line do not differ significantly from each other $(\mathrm{P}>0.05)$. Means with equal lowercase letters in the same column do not differ significantly from each other $(\mathrm{P}>0.05)$.

A: Fermented dairy beverage with $4 \%$ sugar, $60 \%$ papaya pulp, and $40 \%$ orange pulp; B: Fermented dairy beverage with $4 \%$ sugar, $50 \%$ papaya pulp, and $50 \%$ orange pulp; C: Fermented dairy beverage with $7 \%$ sugar, $60 \%$ papaya pulp, and $40 \%$ orange pulp; D: Fermented dairy beverage with $7 \%$ sugar, $50 \%$ papaya pulp, and $50 \%$ orange pulp; E: Fermented dairy beverage with $10 \%$ sugar, $60 \%$ papaya pulp, and $40 \%$ orange pulp; F: Fermented dairy beverage with $10 \%$ sugar, $50 \%$ papaya pulp, and $50 \%$ orange pulp. 
limit for coliforms at $45{ }^{\circ} \mathrm{C}$ is $5.0 \times 10^{3}$ whereas the acceptable limit for Staphylococcusaureus is $1.0 \times 10^{3}$. For Salmonella spp., the requirement is that the product does not present any count of this microorganism;i.e.,this microorganism should not be present in the product (BRASIL, 2001). As shown in table 3, analyses of coagulase positive Staphylococcus and coliforms at $45^{\circ} \mathrm{C}$ remained within the required standards, and presented counts lower than $1.0 \times 10^{1}$ for all samples analyzed on the first day of refrigeration storage. The same can be observed in the analyses of composite samples for Salmonella sp. In which all the results were absent for all the samples in question.

\section{Sensory acceptance}

After the microbiological evaluation of coliforms at $45{ }^{\circ} \mathrm{C}$, Salmonella sp. and Staphylococcus aureus according to Brazilian legislation, the acceptance study was carried out with the participation of 90 consumers. Averages and standard deviation of acceptance are presented in table 4. Beverages that presented in their formulations a higher percentage of papaya pulp with lower and intermediate sugar levels were the most accepted ones. They did not differ significantly from the beverage with the balance of papaya pulp and orange pulp. The beverages with the highest level of sugar in its formulation were the least accepted by these individuals.

Sample C (mean 6.9), sample A (mean 6.7), and sample D (mean 6.4) reached the highest mean values for acceptance and did not differ ( $P>0.05$ ) from each other. MATOS (2009) prepared 6 formulations of milk beverage with $25 \%$ of graviola pulp with different amounts of sugar $(12 \%, 14 \%$, and

Table 3 - Enumeration of filamentous fungi and yeasts, Salmonella sp. (composite sample).

\begin{tabular}{lc}
\hline Microorganism & Counting \\
\hline Filamentous fungi and yeasts & $<1.0 \times 10^{1} \mathrm{CFU} / \mathrm{g}$ \\
Salmonella sp. & Absent (in $25 \mathrm{~mL})$ \\
$\begin{array}{l}\text { Coagulase positive } \\
\text { staphylococci }\end{array}$ & $<1.0 \times 10^{1} \mathrm{CFU} / \mathrm{g}$ \\
Coliforms at $45^{\circ} \mathrm{C}$ & $<1.0 \times 10^{1} \mathrm{CFU} / \mathrm{g}$ \\
\hline
\end{tabular}

(*) Results for all samples.

Coagulase positive staphylococci and coliforms at $45^{\circ} \mathrm{C}$ for fermented milk beverage samples added with ABT- 5 mixed probiotic culture.
$16 \%$ ). Results showed that a concentration of more than $12 \%$ in beverages decreased the preference of consumers since the sweetness excelled to the flavor and scent of graviola. In contrast, beverages $\mathrm{E}$ and $\mathrm{F}$ were the least preferred by consumers in this study. JOHANSEN et al. (2011) corroborated in their study "Motivation to choose and perceive healthy dairy products with reduced calories. A cross-cultural study" that consumers' top, main reasons for choosing low-calorie yogurts and cheeses were related to low fat, health, and taste. In addition, they also had an influence on weight control, nutritional aspects, availability, and lifestyle. The study group presented in table 5 was composed of male consumers (58\%) and women consumers (42\%) mostly (54\%) aged 1825 years old and 26-35 years old, young adults with high level of schooling (54\% of these individuals had postgraduate degrees). Awareness of the benefits of balanced diets leads to healthier consumption habits and health care, exercising and, as a result, reflects in choices for products with different nutritional characteristics. Evidently, the sensorial characteristics of the samples may influence the preference. In this study, there was a preference for samples with low sugar level in detriment to samples with high sugar content (E and F).

Results of the present study showed the preference among consumers for samples with lower sugar contents and intermixtures in counterpoint to the sweeter samples. Vollunteers leaned towards samples with higher proportion of papaya in its formulation as observed by the Internal Preference Map presented in figure 2.

The 6 samples are shown in figure 2 (a) and the distribution of the 90 consumers are shown in figure 2 (b). The sum of components 1 and 2 (F1 and F2) represented $63.39 \%$ of the variation of the data. Based on the data presented in figure 2 (a), with the first component (F1: 45.97\%), we are able to identify the proximity between samples A, $\mathrm{C}$ and $\mathrm{B}, \mathrm{D}$ located to the right of the $\mathrm{X}$ axis. In contrast, samples E and F located on the opposite side of the axis denote negative correlation with the samples mentioned above. It is observed that the distribution of the consumers presented in figure 2 (b) is accentuated to the right of the $\mathrm{X}$ axis in which samples with $40 \mathrm{~g}$ or $70 \mathrm{~g}$ of sugar and 180 $\mathrm{mL}$ of papaya pulp and $120 \mathrm{~mL}$ of orange pulp or $150 \mathrm{~mL}$ of papaya pulp and $150 \mathrm{~mL}$ of orange pulp are located. These observations suggested that these samples were the most accepted ones by consumers. 
Table 4 - Averages and (standard deviation) of acceptance ${ }^{\S}$ of the samples of fermented milk beverage.

\begin{tabular}{lcccccc}
\hline & A & B & C & D & E \\
\hline Acceptance $(n=90)$ & $6.7 \pm(1.9)^{\mathrm{ab}}$ & $6.2 \pm(1.7)^{\mathrm{b}}$ & $6.9 \pm(1.8)^{\mathrm{a}}$ & $6.4 \pm(1.8)^{\mathrm{ab}}$ & $5.2 \pm(1.8)^{\mathrm{c}}$ & $5.1 \pm(2.0)^{\mathrm{c}}$ \\
\hline
\end{tabular}

$\S$ Validated in a 9-point hedonic scale ranging from 1 (dislike extremely) to 9 (like extremely).

Same letters in the same row did not differ significantly $(\mathrm{P} \leq 0.05)$ by the Tukey test.

A: Fermented dairy beverage with $4 \%$ sugar, $60 \%$ papaya pulp, and $40 \%$ orange pulp; B: Fermented dairy beverage with $4 \%$ sugar, $50 \%$ papaya pulp, and 50\% orange pulp; C: Fermented dairy beverage with $7 \%$ sugar, $60 \%$ papaya pulp, and $40 \%$ orange pulp; D: Fermented dairy beverage with $7 \%$ sugar, $50 \%$ papaya pulp and $50 \%$ orange pulp; E: Fermented dairy beverage with $10 \%$ sugar, $60 \%$ papaya pulp and $40 \%$ orange pulp; F: Fermented dairy beverage with $10 \%$ sugar, $50 \%$ papaya pulp and $50 \%$ orange pulp.

Consumersare expected to rejectproducts that have sugar reduction because they do not meet sensory expectations even though these products are healthier in comparison with ordinary products (CIVILLE \& OFTEDAL, 2012). Therefore, emphasizing healthrelated claims that there has been a reduction of sugar in the product may generate negative sensory expectations and decrease consumer acceptance (BRUNNER et al., 2010; LÄHTEENMÄKI et al., 2010). In contrast, according to VERBEKE (2005) and CIVILLE \& OFTEDAL (2012); although, most consumers are not willing to give up the sensory aspects of food even if their consumption is harmful to health, a particular consumer niche more concerned with health can react positively to claims about reduced sugar consumption.

Table 5 - Consumersociodemographic profile (\%).

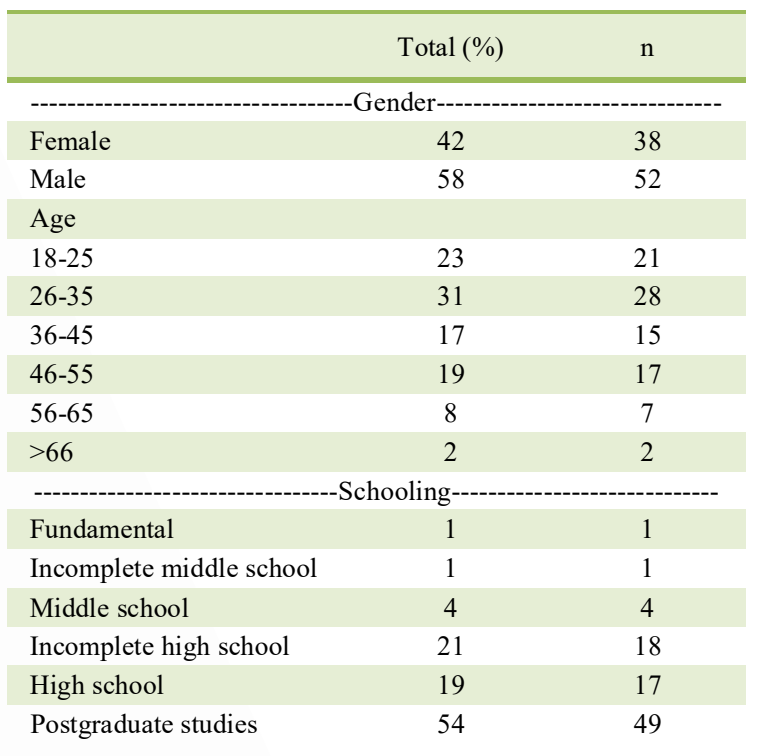

According to table 6, attributes most often checked by consumers in the questionnaire were attractive color, orange flavor, and good consistency. For the best evaluated samples (samples A, C, and D), the attributes related to fruit flavor and good consistency were the most cited ones by tasters which may have contributed to the means of acceptance obtained in this study. In turn, for the samples with the lowest averages of acceptance (E and F), the most cited attributes were fermented flavor, attractive color, and acidity. Figure 3 shows the main attributes with the greatest impact on the evaluation of fermented milk beverage samples. Cochran's Q test was used to determine which attributes influenced the means of acceptance of samples (MANOUKIAN, 1986).

For sample A, with the second highest mean of acceptance in our study, the good consistency and equilibrium attributes raised the mean acceptance. In turn, mention was made to the verysweet attribute as a negative factor and decreased the aforementioned mean. In sample B, the good consistency and equilibrium (balance) attributes were determinant in the sample mean. With regard to sample $C$, the very sweet attribute negatively influenced the evaluation of said sample. However, it was still the one that presented the highest mean of acceptance among all 6 samples of the study; although, it did not differ from beverages A and D. Similar to sample A, the attribute has equilibrium (it is well-balanced) and good consistency were those that contributed positively to the sample mean. For beverage D, the attributes of goodconsistency and equilibrium (balance) were determinant in the mean of the sample and showed to be the only one that does not present a specific 


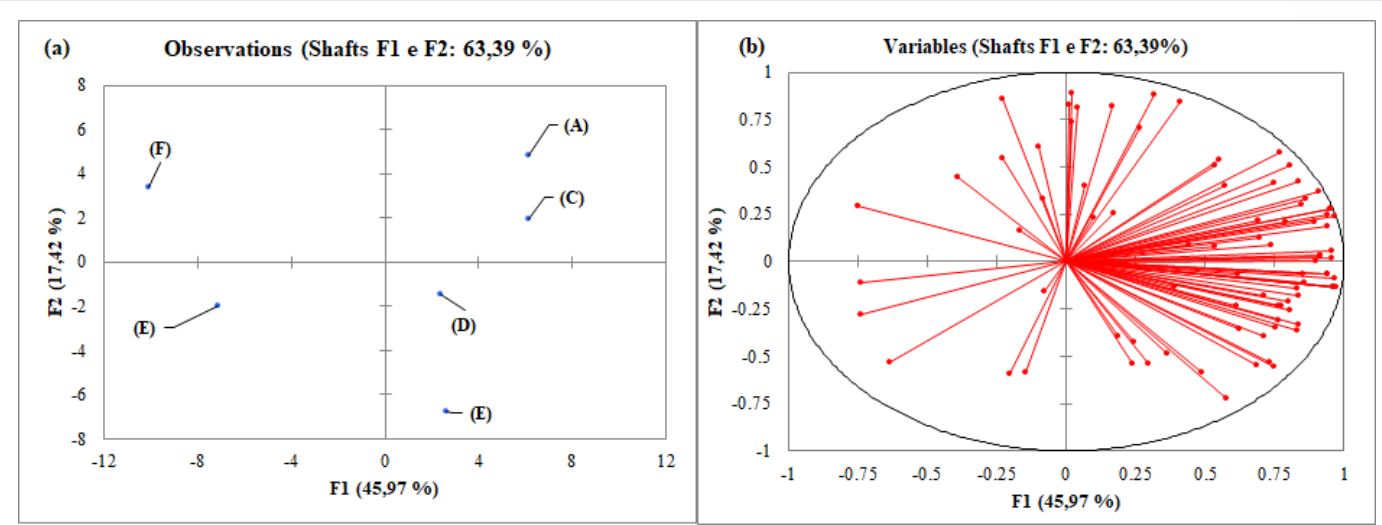

Figure 2 - Internal Preference Map. Positioning of fermented milk beverage samples (a) and consumers' position (b).

attribute as impacting in the decreasel of the mean of acceptance. Samples E and F were the ones with lower means of acceptance and were similar with regard to the attribute low consistency. In 3 of the 6 samples analyzed, the inconsistent attribute was mentioned as a negative factor, thus influencing the acceptance

Table 6 - Frequency (\%) that each of the terms of the CATA questions was checked for sensory description of the fermented milk beverage samples.

\begin{tabular}{|c|c|c|c|c|c|c|}
\hline Characteristics & A & $\mathrm{B}$ & $\mathrm{C}$ & $\mathrm{D}$ & $\mathrm{E}$ & $\mathrm{F}$ \\
\hline Acidic $^{* *}$ & 8.64 & 22.22 & 18.52 & 14.81 & 45.68 & 38.27 \\
\hline Lowacidic $^{\text {ns }}$ & 20.99 & 22.22 & 19.75 & 22.22 & 23.46 & 25.93 \\
\hline Very sweet $^{* *}$ & 27.16 & 7.41 & 30.86 & 7.41 & 0.00 & 1.23 \\
\hline Sweet ${ }^{* *}$ & 38.27 & 35.80 & 32.10 & 33.33 & 7.41 & 4.94 \\
\hline Well-balanced $^{* *}$ & 46.91 & 28.40 & 40.74 & 56.79 & 27.16 & 30.86 \\
\hline Goodconsistency $^{* *}$ & 77.78 & 49.38 & 66.67 & 58.02 & 33.33 & 34.57 \\
\hline Lowconsistency $^{* *}$ & 8.64 & 22.22 & 13.58 & 18.52 & 32.10 & 43.21 \\
\hline Attractive color ${ }^{* *}$ & 72.84 & 60.49 & 66.67 & 59.26 & 51.85 & 49.38 \\
\hline Fermented flavor ${ }^{*}$ & 39.51 & 43.21 & 38.27 & 41.98 & 54.32 & 46.91 \\
\hline Orange flovored ${ }^{* *}$ & 54.32 & 76.54 & 71.60 & 59.26 & 53.09 & 44.44 \\
\hline Papaya flavored ${ }^{* *}$ & 59.26 & 40.74 & 40.74 & 53.09 & 27.16 & 35.80 \\
\hline Fermented scent ${ }^{\mathrm{ns}}$ & 25.93 & 38.27 & 24.69 & 30.86 & 35.80 & 30.86 \\
\hline Sweet-scented $^{* *}$ & 29.63 & 17.28 & 23.46 & 17.28 & 9.88 & 9.88 \\
\hline Soft (smooth)-scented ${ }^{* *}$ & 41.98 & 45.68 & 43.21 & 49.38 & 37.04 & 34.57 \\
\hline Homogeneousappearance ${ }^{* *}$ & 55.56 & 35.80 & 49.38 & 43.21 & 38.27 & 33.33 \\
\hline Sandy ${ }^{\text {ns }}$ & 3.70 & 14.81 & 4.94 & 6.17 & 8.64 & 9.88 \\
\hline
\end{tabular}

${ }^{* *}(\mathrm{P} \leq 0.001) ;{ }^{*}(\mathrm{P} \leq 0.01)$ according to Cochran's $\mathrm{Q}$ test $\mathrm{ns}=$ did not differ significantly $(\mathrm{P}>0.05)$ according to the Cochran $\mathrm{Q}$ test. A: Fermented dairy beverage with $4 \%$ sugar, $60 \%$ papaya pulp, and $40 \%$ orange pulp; B: Fermented dairy drink with $4 \%$ sugar, $50 \%$ papaya pulp, and 50\% orange pulp; C: Fermented dairy drink with $7 \%$ sugar, $60 \%$ papaya pulp, and $40 \%$ orange pulp; D: Fermented dairy drink with $7 \%$ sugar, $50 \%$ papaya pulp, and $50 \%$ orange pulp; E: Fermented dairy drink with $10 \%$ sugar, $60 \%$ papaya pulp, and $40 \%$ orange pulp; F: Fermented dairy drink with $10 \%$ sugar, $50 \%$ papaya pulp, and $50 \%$ orange pulp. 


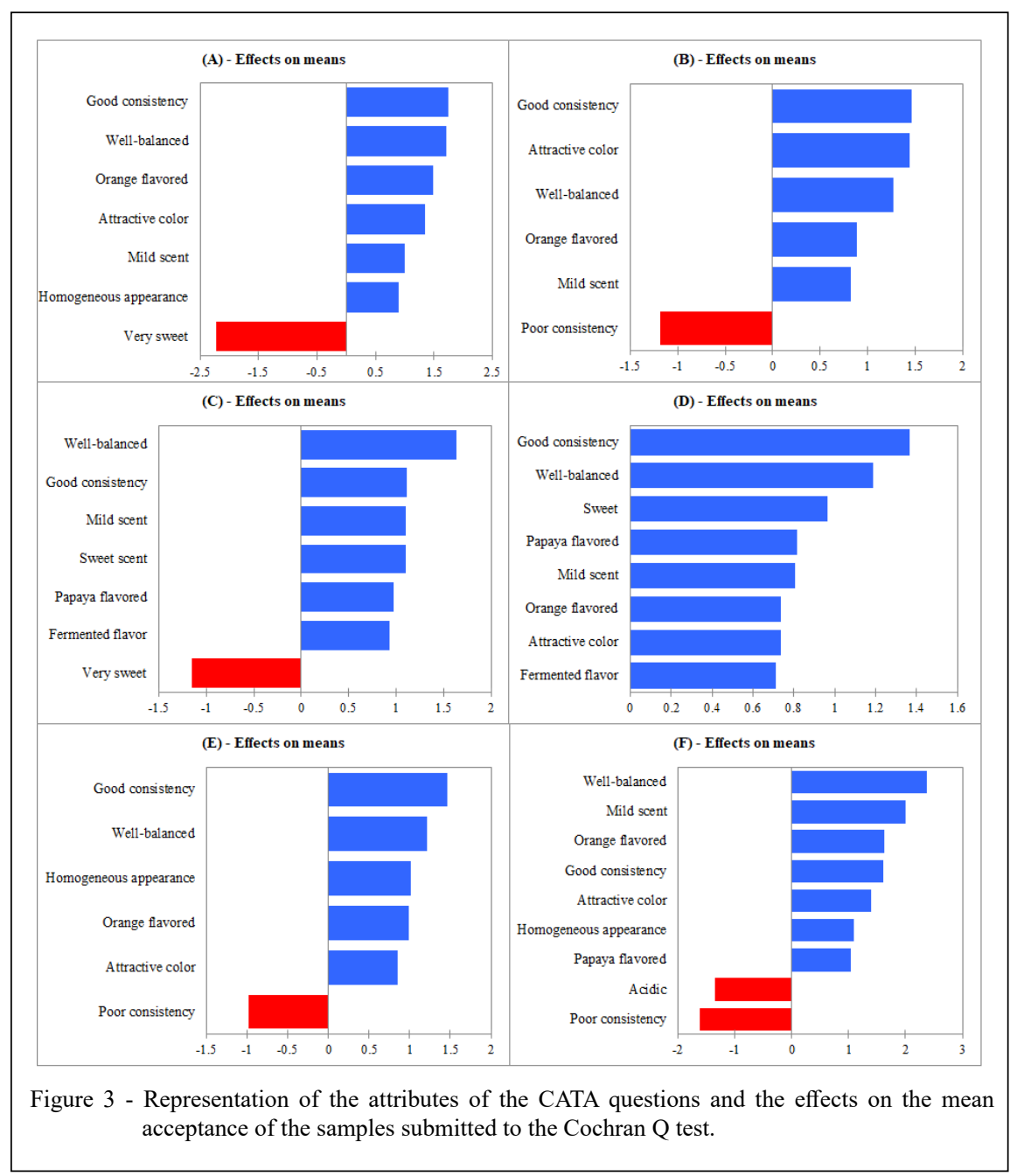

means of the samples. In contrast, good consistency and equilibrium (it is well-balanced) attributes were mentioned as positive in all samples.

\section{CONCLUSION}

Orange flavored and papaya flavored fermented milk beverage with mixed probiotic culture was adequate for the microbiological safety requirements at the earlier stages of refrigeration. It is; therefore, feasible to provide the functional characteristics concerning the viability and the required population of probiotic microorganisms. Use of probiotics in conjunction with formulations with higher sugar levels as shown in previous studies published elsewhere by other authors showed the highest enumerations of L. acidophilus and sensorially obtained the lowest averages of global acceptance. Samples A (40 g of sugar, $180 \mathrm{~mL}$ of papaya pulp, and $120 \mathrm{~mL}$ of orange pulp) and $\mathrm{C}(70 \mathrm{~g}$ of sugar, $180 \mathrm{~mL}$ of papaya pulp, and $120 \mathrm{~mL}$ of orange pulp) were described by the CATA questions as having good consistency, balance, soft scent, attractive color, and homogeneous aspect. In turn, samples E (100 g of sugar, $180 \mathrm{~mL}$ of papaya pulp, and $120 \mathrm{~mL}$ of orange pulp) and $\mathrm{F}$ (70 g sugar, $150 \mathrm{~mL}$ of papaya pulp, and $150 \mathrm{~mL}$ of orange pulp) showed a correlation with attributes low consistency and acidic. The higher added sugar content seems to have been determinant for the low mean acceptance. It should be considered that additionalin-depth studies are conducted with correlation between consumer behavior and

Ciência Rural, v.49, n.3, 2019. 
decreased amounts of sugar in foods. Considering the current trends for reducing sugar content in food formulations and consequently contributing to the continuous decrease of sugar consumption, e formulation A (with $40 \mathrm{~g}$ of sugar, $180 \mathrm{~mL}$ of papaya pulp, and $120 \mathrm{~mL}$ of orange pulp) as the "ideal" for the development of the beverage, even if statistically it did not present significant difference with sample B (with $70 \mathrm{~g}$ of sugar, $150 \mathrm{~mL}$ of papaya pulp, and 150 $\mathrm{mL}$ of orange pulp).

\section{ACKNOWLEDGMENTS}

The authors gratefully acknowledge Fundação Carlos Chagas de Amparo à Pesquisa do Estado do Rio de Janeiro (FAPERJ), Brazil, for funding our research and Coordenação de Aperfeiçoamento de Pessoal de Nível Superior (CAPES), for the scholarship granted to graduate students and researches.

\section{BIOTHICS AND BIOSECURITY COMMITTEE APROVAL}

Certificado de Apresentação para Apreciação Ética (CAAE): 55023416.0.0000.5285.

\section{DECLARATION OF CONFLICTING INTERESTS}

The authors declare no conflict of interest. The founding sponsors had no role in the design of the study; in the collection, analyses, or interpretation of data; in the writing of the manuscript, and in the decision to publish the results.

\section{AUTHORS' CONTRIBUTIONS}

All authors contributed equally for the conception and writing of the manuscript. All authors critically revised the manuscript and approved of the final version.

\section{REFERENCES}

ALEXI, N., et al. Check-All-That-Apply (CATA) with semitrained assessors: Sensory profiles closer to descriptive analysis or consumer elicited data? Food Quality and Preference, v.64, p.1120. 2018. Available from: $<$ http://www.sciencedirect.com/science/ article/pii/S0950329317302483>. Accessed: Mar. 01, 2018. doi: 10.1016/j.foodqual.2017.10.009.

ALI, Z. M., et al. A comparative study on wall degrading enzymes, pectin modifications and softening during ripening of selected tropical fruits. Plant Science, v.167, n.2, p.317-327. 2004. Available from: $<$ http://www.sciencedirect.com/science/article/pii/ S0168945204001530>. Accessed: Mar. 15, 2018. doi: 10.1016/j. plantsci.2004.03.030.

AOAC. Official Methods of Analysis. EUA: Association of Official Analytical Chemist, 17th ed. Gaithersburg. 2000.
ARES, G. Methodological challenges in sensory characterization. Current Opinion in Food Science, v.3, p.1-5. 2015. Available from: <http://www.sciencedirect.com/science/ article/pii/S2214799314000058>. Accessed: Mar, 17, 2018. doi: $10.1016 /$ j.cofs.2014.09.001.

ASHRAF, R.; N. P. SHAH. Selective and differential enumerations of Lactobacillus delbrueckii subsp. bulgaricus, Streptococcus thermophilus, Lactobacillus acidophilus, Lactobacillus casei and Bifidobacterium spp. in yoghurt - A review. International Journal of Food Microbiology, v.149, n.3, p.194-208. 2011. Available from: <http:/www.sciencedirect.com/science/article/pii/ S0168160511004004>. Accessed: Mar. 19, 2018. doi: 10.1016/j. ijfoodmicro.2011.07.008.

BALTHAZAR, C., et al. Physicochemical evaluation of sheep milk yogurts containing different levels of inulin. Journal of Dairy Science, v.99, n.6, p.4160-4168. 2016. Available from: <https:// www.ncbi.nlm.nih.gov/pubmed/26995125>. Accessed: Sept. 06, 2018. doi: $10.3168 /$ jds.2015-10072.

BRASIL. Resolução RDC n ${ }^{\circ} 12$, de 02 de janeiro de 2001. Aprova o Regulamento Técnico sobre padrões microbiológicos para alimentos. Anvisa. Diário Oficial da República Federativa do Brasil. 2001.

BRASIL. Instrução Normativa $n^{\circ}$ 62, de 26 de agosto de 2003. Métodos Analíticos Oficiais para Análises Microbológicas para Controle de Produtos de Origem Animal e Água. Mapa. D.O.U. - Diário Oficial da República Federativa do Brasil: 14 p. 2003.

BRASIL. Instrução Normativa $N^{\circ} 16$. Aprova o Regulamento Técnico de Identidade e Qualidade de Bebida Láctea. Mapa. Brasília: D.O.U. - Diário Oficial da República Federativa do Brasil 2005.

BRUNNER, T. A., et al. Convenience food products. Drivers for consumption. Appetite, v.55, n.3, p.498-506. 2010. Available from: <https://www.scopus.com/inward/record.uri?eid=2-s2.078649425536\&doi $=10.1016 \% 2 \mathrm{fj}$. appet.2010.08.017\&partnerID $=40 \& \mathrm{md} 5=\mathrm{d} 9 \mathrm{fd} 87 \mathrm{dade} 565 \mathrm{~d} 897 \mathrm{fe} 382 \mathrm{~b} 636 \mathrm{~b} 4 \mathrm{db} 6 \mathrm{~b}>$. Accessed: May 03, 2018. doi: 10.1016/j.appet.2010.08.017.

CITRUSBR. Benefícios do Suco de Laranja, Associação Nacional dos Exportadores de Sucos Cítricos 2017. Availabre from: $<$ http://www.citrusbr.com/laranjaesuco/?ins=17>. Accessed: Apr. 02, 2018

CIVILLE, G. V.; K. N. OFTEDAL. Sensory evaluation techniques - Make "good for you" taste "good". Physiology and Behavior, v.107, n.4, p.598-605. 2012. Available from: $<$ https://www.scopus.com/inward/record.uri?eid=2-s2.0$84870986356 \&$ doi $=10.1016 \% 2$ fj.physbeh.2012.04.015\&partner $\mathrm{ID}=40 \& \mathrm{md} 5=80 \mathrm{~cd} 42 \mathrm{faa} 8 \mathrm{~d} 740 \mathrm{~b} 2 \mathrm{da} 92 \mathrm{e} 8 \mathrm{eff} 8 \mathrm{a} 8 \mathrm{e} 599>$. Accessed: Aug. 30, 2018. doi: 10.1016/j.physbeh.2012.04.015.

COSTA, M., et al. Changes on expected taste perception of probiotic and conventional yogurts made from goat milk after rapidly repeated exposure. Journal of Dairy Science, v.97, n.5, p.2610-2618. 2014. Available from: <https://www.ncbi.nlm.nih. gov/pubmed/24582442>. Accessed: Mai. 01, 2018. doi: 10.3168/ jds.2013-7617.

FAVA NEVES, M.; V. G. TROMBIN. Anuário da Citricultura. CITRUSBR ,São Paulo: 60 p. 2017. Availabre from: <http://www. 
citrusbr.com/download/biblioteca/CitrusBR_Anuario_2017_alta. pdf>. Acessed: Mar. 21, 2018.

FERNANDES PEREIRA, A. L.; S. RODRIGUES. Turning Fruit Juice Into Probiotic Beverages A2 - Rajauria, Gaurav. In: B. K Tiwari (Ed.). Fruit Juices. San Diego: Academic Press, 2018. Turning Fruit Juice Into Probiotic Beverages A2 - Rajauria Gaurav, p.279-287.

GRYGORCZYK, A., et al. Applying appeal ratings and CATA for making word choices in messaging about food technology. Food Quality and Preference, v.62, p.237-245. 2017. Available from: $\quad<$ http://www.sciencedirect.com/science/article/pii/ S0950329317301386>. Accessed: Mar. 20, 2018. doi: https://doi. org/10.1016/j.foodqual.2017.06.002.

HE, S.; S. HEKMAT. Sensory evaluation of non-dairy probiotic beverages. Jounal of Food Research, v.4, n.1, p.186. 2014 Available from: <http://www.ccsenet.org/journal/index.php/ jfr/article/view/40910/23903>. Accessed: Mar. 16, 2018. doi: $10.5539 /$ jfr.v4n $1 \mathrm{p} 186$.

HITCHINS, A., et al. Escherichia coli and the coliform bacteria. In: A. International (Ed.). Food and Drug Administration Bacteriological Analytical Manual. Escherichia coli and the coliform bacteria, p.4.01-4.29, 1998.

JAYAMANNE, V. S.; M. R. ADAMS. Determination of survival, identity and stress resistance of probiotic bifidobacteria in bioyoghurts. Letters in Applied Microbiology, v.42, n.3, p.189194. 2006. Available from: <https://onlinelibrary.wiley.com/doi/ abs/10.1111/j.1472-765X.2006.01843.x>. Accessed: Mar. 17, 2018. doi: doi:10.1111/j.1472-765X.2006.01843.x.

JOHANSEN, S. B., et al. Motivation for choice and healthiness perception of calorie-reduced dairy products. A cross-cultural study. Appetite, v.56, n.1, p.15-24. 2011. Available from: <http:// www.sciencedirect.com/science/article/pii/S0195666310006847>. Accessed: Mar. 18, 2018. doi: 10.1016/j.appet.2010.11.137.

KIANI, L. Bugs in our guts-not all bacteria are bad: how probiotic keep us healthy. Ulster, UK: CSA Discovery Guides, p.1-21. 2006. Available from: $<$ http://citeseerx.ist.psu.edu/viewdoc/down load?doi=10.1.1.503.8094\&rep $=$ rep1\&type $=$ pdf $>$. Accessed: May 02, 2018. doi.

LÄHTEENMÄKI, L., et al. Impact of health-related claims on the perception of other product attributes. Food Policy, v.35, n.3, p.230-239. 2010. Available from: <https://www.scopus.com/ inward/record.uri?eid $=2-\mathrm{s} 2.0-77952543722 \& \mathrm{doi}=10.1016 \% 2 \mathrm{fj}$. foodpol.2009.12.007\&partnerID $=40 \& \mathrm{md} 5=601732 \mathrm{cfd} 04 \mathrm{df} 8 \mathrm{e}$ ae0ff5f6bd060c86d $>$. Accessed: Apr. 9, 2018. doi: 10.1016/j. foodpol.2009.12.007.

LI, C.; H. SCHLUESENER. Health-promoting effects of the citrus flavanone hesperidin. Critical Reviews in Food Science and Nutrition, v.57, n.3, p.613-631. 2017. Available from: $<$ https://doi. org/10.1080/10408398.2014.906382>. Accessed: Mar. 05, 2018. doi: $10.1080 / 10408398.2014 .906382$.

LOURENS-HATTINGH, A.; B. C. VILJOEN. Growth and survival of a probiotic yeast in dairy products. Food Research International, v.34, n.9, p.791-796. 2001. Available from: <http:// www.sciencedirect.com/science/article/pii/S0963996901000850>. Accessed: Mar. 05, 2018. doi: https://doi.org/10.1016/S09639969(01)00085-0.

MACHADO, T. A. D. G., et al. Impact of honey on quality characteristics of goat yogurt containing probiotic Lactobacillus acidophilus. LWT-Food and Science Technology, v.80, p.221229. 2017. Available from: <http://www.sciencedirect.com/ science/article/pii/S0023643817301123>. Accessed: Mar. 21, 2018. doi: https://doi.org/10.1016/j.lwt.2017.02.013

MANOUKIAN, E. B. Mathematical nonparametric statistics: Gordon and Breach Science Publishers, Inc. 1986.

MASSON, L. M. P. Desenvolvimento de bebida láctea fermentada submetida ao processamento térmico e/ou à homogeneização à ultra-alta pressão. - Curso de Pós-Graduação em Tecnologia de Processos Químicos e Bioquímicos em Engenharia Química, Escola de Química, Universidade Federal do Rio de Janeiro, 2010. 123f p.

MATOS. Desenvolvimento e mapa de preferência externo de bebida láctea a base de soro e polpa de graviola (Annona muricata). - Curso de Pós-Graduação em Engenharia de Alimentos, Universidade Estadual do Sudoeste da Bahia., 2009. 79f p.

MEGÍAS-PÉREZ, R., et al. Survey of quality indicators in commercial dehydrated fruits. Food Chemistry, v.150, p.41 48. 2014. Available from: <https://www.scopus.com/inward/ record.uri?eid $=2-\mathrm{s} 2.0-84887923313 \&$ doi $=10.1016 \% 2 \mathrm{fj}$. foodc hem. 2013.10.141\&partnerID $=40 \& \mathrm{md} 5=653 \mathrm{ce} 9 \mathrm{a} 4 \mathrm{a} 7 \mathrm{a} 815500$ c2c1caeb1ec71a7>. Accessed: Mar. 18, 2018. doi: 10.1016/j. foodchem.2013.10.141.

MOKOENA, M. P., et al. Perspectives on the probiotic potential of lactic acid bacteria from African traditional fermented foods and beverages. Food \& Nutrition Research, v.60. 2016. Available from: $<$ http://www.foodandnutritionresearch.net/index.php/fnr/article/ view/29630>. Accessed: Mar. 23, 2018. doi: 10.3402/fnr.v60.29630.

MOTA, M. J., et al. Probiotic yogurt production under high pressure and the possible use of pressure as an on/off switch to stop/start fermentation. Process Biochemistry, v.50, n.6, p.906911. 2015. Available from: <https://www.sciencedirect.com science/article/pii/S1359511315001579>. Accessed: Mar. 23, 2018. doi: $10.1016 /$ j.procbio.2015.03.016

PEREIRA, R. N., et al. Ohmic heating for the dairy industry: a potential technology to develop probiotic dairy foods in association with modifications of whey protein structure. Current Opinion in Food Science, v.22, p.95-101. 2018. Available from: <http:// www.sciencedirect.com/science/article/pii/S2214799318300109>. Accessed: Mar. 21, 2018. doi: 10.1016/j.cofs.2018.01.014.

PRADO, F. C., et al. Trends in non-dairy probiotic beverages. Food Research International, v.41, n.2, p.111-123. 2008. Available from: $<$ https://www.sciencedirect.com/science/article/pii/ S0963996907001883>. Accessed: May 01, 2018. doi: 10.1016/j. foodres.2007.10.010.

SAÚCO, V. G., et al. Tropical and subtropical fruits. In: (Ed.). Horticulture: Plants for People and Places: Springer, v.1, 2014. Tropical and Subtropical Fruits, p.123-157

SEBRAE. O cultivo e o mercado do mamão. 2016. Available from: $\quad<$ http://www.sebrae.com.br/sites/PortalSebrae/artigos/ocultivo-e-o-mercado-do-mamao,937a9e665b182410VgnVCM100 000b272010aRCRD>. Accessed: May 02, 2018.

SHORI, A. B.; A. S. BABA. Antioxidant activity and inhibition of key enzymes linked to type-2 diabetes and hypertension by Azadirachta indica-yogurt. Journal of Saudi Chemical Society, v.17, n.3, p.295-301. 2013. Available from: <http://www. sciencedirect.com/science/article/pii/S1319610311000755>. Accessed: Apr. 10, 2018. doi: 10.1016/j.jscs.2011.04.006. 
SU, N., et al. Antioxidant activity and flavor compounds of hickory yogurt. International Journal of Food Properties, v.20, n.8, p.1894-1903. 2017. Available from: <https://doi.org/1 0.1080/10942912.2016.1223126>. Accessed: Mar. 18, 2018. doi: $10.1080 / 10942912.2016 .1223126$

TOURNAS, V., et al. Yeasts, molds and mycotoxins. Bacteriological analytical manual. 8th ed. Revision A. US Food and Drug Administration, Washington, DC. 2001. Available from. doi: Accessed: Apr. 05,2018.

URIOT, O., et al. Streptococcus thermophilus: From yogurt starter to a new promising probiotic candidate? Journal of Functional Foods, v.37, p.74-89. 2017. Available from: <http:// www.sciencedirect.com/science/article/pii/S1756464617304267>. Accessed: Apr. 03, 2018. doi: 10.1016/j.jff.2017.07.038.

VAN HOOIJDONK, T.; K. HETTINGA. Dairy in a sustainable diet: a question of balance. Nutrition Reviews, v.73, n.suppl_1, p.48-54. 2015. Available from: <http://dx.doi.org/10.1093/nutrit/ nuv040>. Accessed: Mar. 18, 2018. doi: 10.1093/nutrit/nuv040.

VAN KLEEF, E., et al. Internal versus external preference analysis: An exploratory study on end-user evaluation. Food Quality and Preference, v.17, n.5, p.387-399. 2006. Available from: <https://www.sciencedirect.com/science/article/abs/pii/ S095032930500073X>. Accessed: Apr. 04, 2018. doi: 10.1016/j. foodqual.2005.05.001.

VARELA, P.; G. ARES. Novel Techniques in Sensory Characterization and Consumer Profiling: CRC Press. 2014. VERBEKE, W. Consumer acceptance of functional foods: Sociodemographic, cognitive and attitudinal determinants. Food
Quality and Preference, v.16, n.1, p.45-57. 2005. Available from: $\quad<$ https://www.scopus.com/inward/record.uri?eid=2-s2.0$5744238395 \&$ doi $=10.1016 \% 2$ fj.foodqual.2004.01.001\&partnerI $\mathrm{D}=40 \& \mathrm{md} 5=0 \mathrm{e} 38 \mathrm{f} 0 \mathrm{fcb} 300775071 \mathrm{f} 895 \mathrm{dddf0} 01781 \mathrm{c}>$. Accessed: Apr. 05, 2018. doi: 10.1016/j.foodqual.2004.01.001.

YERLIKAYA, O. Starter cultures used in probiotic dairy product preparation and popular probiotic dairy drinks. Food Science and Technology (Campinas), v.34, p.221-229. 2014. Available from: $<$ http://www.scielo.br/scielo.php?script $=$ sci arttext\&pid=S010120612014000200001\&nrm=iso >. Accessed: Mar. 23, 2018. doi: $10.1590 /$ fst.2014.0050.

ZHANG, R., et al. Physico-chemical properties and hypoglycaemic activity of fermented milks prepared with Anemarrhena asphodeloides water extracts. Journal of the Science of Food and Agriculture, v.96, n.2, p.492-496. 2016. Available from: $<$ https:// onlinelibrary.wiley.com/doi/abs/10.1002/jsfa.7115>. Accessed: Mar. 18, 2018. doi: doi:10.1002/jsfa.7115.

ZHENG, X., et al. Comparing product stability of probiotic beverages using litchi juice treated by high hydrostatic pressure and heat as substrates. Innovative Food Science \& Emerging technologies, v.23, p.61-67. 2014. Available from: <http://www. sciencedirect.com/science/article/pii/S1466856414000253>. Accessed: Mar. 14, 2018. doi: 10.1016/j.ifset.2014.01.013.

ZOUMPOPOULOU, G., et al. Dairy probiotics: Beyond the role of promoting gut and immune health. International Dairy Journal, v.67, p.46-60. 2017. Available from: <http://www.sciencedirect. com/science/article/pii/S0958694616303077> . Accessed: Mar. 17, 2018. doi: 10.1016/j.idairyj.2016.09.010. 